\title{
Л.В. Зайцева
}

\section{ЭКОНОМИЧЕСКИ ЗАВИСИМЫЕ САМОЗАНЯТЫЕ: РАЗЛИЧИЯ НАЦИОНАЛЬНЫХ ПОДХОДОВ К ОПРЕДЕЛЕНИЮ ПРАВОВОГО СТАТУСА}

\begin{abstract}
Исследованы различные национальные подходы к регулированию труда экономически зависимых самозанятых на основе сравнения законодательства и судебной практики России, Испании, Германии, США и других стран. Определены существующие в мире способы искоренения вредных практик социального демпинга в сфере труда. В результате выявлены дефекты в приоритетах правовой политики РФ в области регулирования деятельности самозанятых. Сделан вывод о возникновении в РФ рисков ухудшения условий труда и занятости.

Ключевые слова: действие трудового права по кругу лиц; самозанятые; коллективный договор; трудовое отношение; минимальная зарплата.
\end{abstract}

\section{Введение}

Современный рынок труда становится гораздо более гибким. Часто можно наблюдать переход работников из категории наемных работников в категорию самозанятых. Возник даже термин «уберизация» экономики, когда такие онлайн-посредники, как Uber, стали связывать самозанятых с клиентами, вытесняя сотрудников, подпадающих под защиту трудового законодательства. Хотя сама по себе экономическая основа для искусственного сужения круга лиц, находящихся под защитой трудового права, возникла гораздо раньше и была связана не столько с цифровой экономикой, сколько со стремлением снижения издержек, повышения экономической эффективности, конкурентоспособности, в том числе и с помощью применения различных форм аутсорсинга. Существующая сегодня статистика ясно показывают, что во многих государствах самозанятые составляют значительную долю рабочей силы, а процент самозанятости растет во многих государствах. Разрыв между охраняемым трудовым законодательством работником и осуществляющим на свой страх и риск деятельность самозанятым часто приводит к ухудшению условий труда и тех и других. В Европейском Союзе это принято называть социальным демпингом, а в США - вредной или нечестной конкуренцией. Результатом расширения этих явлений становятся уменьшение размера компенсаций, ухудшение условий труда, коррозия норм профессиональной практики как для работников, так и для самозанятых, а также снижение социального диалога все это вместе в значительной степени способствует серьезному экономическому неравенству.

В «серую часть» между трудоправовым и гражданско-правовым регулированием попадают, прежде всего, те работники и самозанятые, чьи отношения с работодателем или заказчиком носят атипичный характер. Со стороны работников это, прежде всего, фрилансеры (дистанционные работники). Если говорить о самозанятых, то это те из них, кто оказывает услуги заказчику лично и по факту находится от него в существенной зависимости.

\section{Актуализация феномена самозанятости в современной России}

Трудовое законодательство РФ не дает адекватного понятия «самозанятый» вообще и «экономически зависимый самозанятый» тем более. Под самозанятым, мы вслед за Межгосударственным стандартом (ГОСТ 12.0.004-2015. Межгосударственный стандарт. Система стандартов безопасности труда. Организация обучения безопасности труда. Общие положения) понимаем лиц, самостоятельно занятых трудом по оказанию услуг в рамках договоров гражданскоправового характера, в том числе в форме индивидуального предпринимательства.

В современной России внимание к самозанятым и их правовому статусу связано с попытками вывода из тени доходов граждан, не зарегистрированных в качестве индивидуальных предпринимателей, но имеющих более-менее постоянный доход от лично предоставляемых ими услуг.

Сначала в ст. 83 Налогового кодекса РФ вводится норма о регистрации в качестве налогоплательщиков физических лиц, не являющихся индивидуальными предпринимателями, но оказывающих услуги другим физическим лицам «для личных, домашних и (или) иных подобных нужд» [1]. До конца 2019 г. самозанятые освобождаются от уплаты налогов на доходы, полученные ими от услуг, перечисленных в п. 70 ст. 217 Налогового кодекса РФ, но должны зарегистрироваться в соответствующем качестве в налоговых органах. Немного позднее в ст. 23 Гражданского кодекса РФ вносится норма, позволяющая физическим лицам осуществлять отдельные виды предпринимательской деятельности без государственной регистрации в качестве индивидуального предпринимателя [2]. Далее принимается Федеральный закон, которым учреждается эксперимент по взиманию налога на профессиональный доход с самозанятых в Москве, Московской и Калужской областях и Татарстане с 1 января 2019 г. по 31 декабря 2028 г. [3]. Цель этих законов очевидна - «вывод из тени самозанятых» [4, 5]. Причем имеются в виду не все самозанятые, как их определяет вышеназванный международный стандарт, а лишь незначительная их часть - физические лица: 1) оказывающие услуги другим физическим лицам; 2) оказывающие услуги, связанные с удовлетворением личных, хозяйственных и других нужд (установлен перечень видов деятельности, при котором спецрежим не может применяться); 3) не имеющие работников (работающих у них по трудовому договору, хотя и без запрета на заключения с другими 
физическими лицами договоров гражданскоправового характера в качестве заказчиков); 4) с годовым доходом, не превышающим 2,4 млн руб.

Насколько масштабна и одновременно сложна проблема вывода из тени доходов самозанятых в РФ, свидетельствуют данные об их численности, представляемые различными российскими ведомствами. С одной стороны, по данным Федеральной налоговой службы, с 1 января 2018 г. по состоянию на 1 января 2019 г. в России зарегистрировано всего 2123 самозанятых [6]. С другой стороны, по оценкам Росстата, число самозанятых в стране может достигать 15 млн человек [7], Минэкономразвия - 30 млн человек [8]. Из них как минимум для 3,5 млн человек доходы от самозанятости являются основным источником дохода [9].

Несмотря на высказываемые представителями властей оптимистичные прогнозы относительно введения специального режима (налога на профессиональный доход в субъектах РФ, где федеральным законом объявлен эксперимент) для самозанятых [10], появляются очень сдержанные мнения экспертов относительно его эффективности [11] и также тревожные сообщения о нарушении прав работников путем принуждения их работодателем к регистрации в качестве самозанятых [12].

Смещение акцента государственной политики на вывод доходов самозанятых из тени не только создает риски искусственного вывода части работников из сферы действия трудового права, но и реальные предпосылки для легального сужения круга лиц, чей труд регулируется нормами трудового права. Речь идет о законопроекте по внесению изменений в Трудовой кодекс РФ, подготовленный Минтрудом России и предусматривающий исключение из сферы действия трудового права всех лиц, оказывающих услуги физическим лицам, в том числе в области помощи по хозяйству [13]. Конечно, можно говорить, что сегодня нормы гл. 48 ТК РФ практически не применяются изза нежелания работодателей - физических лиц легализовывать трудовые отношения с домашними работниками. Тем не менее существование в ТК РФ соответствующих норм обеспечивает возможность защиты трудовых прав таких работников, в том числе и судебной. Исключение же их из числа субъектов трудовых отношений хоть и является логичным продолжением легализации их доходов в целях налогообложения, но лишает их всех трудовых прав, установленных трудовым законодательством.

\section{Работник, индивидуальный предприниматель, самозанятый: решение проблем искусственной подмены статуса средствами трудового права}

На самом деле, формальная или неформальная, легальная или нелегальная самозанятость, во всех случаях речь может идти о фактической подмене фигуры работника на самозанятого, или (и) на индивидуального предпринимателя.

До недавнего времени казалось, что проблема абсолютно решаема путем применения ч. 2 ст. 15 и ч. 7 ст. 11 ТК РФ, позволяющих признать через суд отношения, возникшие из гражданско-правового договора трудовыми, в том числе и с исполнителем - индивидуальным предпринимателем. И такие судебные решения имеются в российской судебной практике по искам лиц, зарегистрированных в качестве индивидуальных предпринимателей, но фактически вступивших в трудовые отношения и стремящихся восстановить свои нарушенные трудовые права [14]. Устойчивости такой судебной практики способствуют содержание ч. 1 ст. 15 ТК РФ, четко закрепившей признаки трудового правоотношения, а также официальная позиция Верховного Суда РФ, еще раз в 2018 г. подробнейшим образом описавшего признаки трудового отношения и возможные доказательства его возникновения [15].

Кроме того, имеется административная практика налоговых органов, которые при проведении проверок устанавливают случаи, когда в целях занижения налоговой базы и получения необоснованной налоговой выгоды по НДС и НДФЛ осуществляется привлечение индивидуальных предпринимателей по договорам гражданско-правового характера, при этом физические лица, зарегистрированные в качестве предпринимателей, фактически являются работниками и по договорам гражданско-правового характера выполняют свои трудовые функции. В таких случаях суды также осуществляют переквалификацию гражданскоправовых отношений в трудовые с последующими налоговыми последствиями [16].

Но, несмотря на это, практика перевода части работников в категорию индивидуальных предпринимателей до сих пор не иссякает, в том числе в отсутствие сопротивления самих работников и слабой профсоюзной защиты. Соответственно, нет никакой гарантии, что очень скоро судебная практика в РФ не обогатится решениями о признании трудовыми отношений с самозанятыми лицами. Хотя судебные перспективы здесь могут быть гораздо более туманными. Ведь признание отношений трудовыми, если с лицом необоснованно заключен гражданско-правовой договор об оказании услуг или выполнении работ, проистекает из сравнения сходных между собой по объекту правоотошений. Суд всегда с более-менее высокой долей вероятности может выяснить, выполнялась ли трудовая функция или конкретно определенная, имеющая свое объективное измерение и окончание работа; имело ли место подчинение работника (исполнителя) воле работодателя (заказчика), являлся ли труд самостоятельным или выполнялся под контролем и управлением и т.п. А если работник выводится за рамки организационной структуры бывшего работодателя и продолжает оказывать те же услуги населению, что и ранее как работник этого работодателя, но теперь напрямую и непосредственно заказчику - физическому лицу, при этом с бывшим работодателем его продолжает связывать только, например, договор аренды или франчайзинга? Бывший работник продолжает неформально находиться под контролем бывшего работодателя, который имеет от работника уже «чистый доход» в виде арендной платы или франшизы, не неся никаких издержек на рабочую силу. При этом и у самого работника снижаются налоговые платежи. Представляется, что перед нами но- 
вый соблазн нечестной «оптимизации налогообложения», отягощенный снижением уровня социальной защиты фактического работника. И это при том, что нынешнее трудовое законодательство РФ не имеет адекватных инструментов защиты прав фактического работника в этом случае, поскольку такой самозанятый никаких работ или услуг в пользу благоприобретателя - юридического лица не осуществляет.

Что же касается вопроса признания трудовыми отношений с индивидуальным предпринимателем, то аналогичный российским правилам подход существует и в ряде других стран, и не только постсоветского пространства. Например, в Польше нормативные акты позволяют однозначно квалифицировать любые правовые отношения, которые проявляют определенные черты, как трудовые отношения [17]. Верховный Суд Польши постановил, что когда физическое лицо является предпринимателем, но заключает договор, который имеет некоторые признаки трудового договора, такое лицо не действует в рамках своей предпринимательской деятельности, и поэтому отсутствуют препятствия для признания этого лица работником [18] При том, что в Польше с 2018 г. (как и в России с 2014) с работником допускается заключение исключительно трудового договора [19].

Таким образом, самозанятого подрядчика и (или) индивидуального предпринимателя, заключившего в качестве исполнителя гражданско-правовой договор, предметом которого является выполнение работ или оказание услуг, можно признать работником, если национальное трудовое законодательство содержит нормы, аналогичные тем, что действуют в России или в Польше.

Но это далеко не единственный подход к решению вопроса искоренения «социального демпинга», вызываемого недобросовестным применением труда самозанятых. Особенно той их части, которая организационно и экономически зависит от основного заказчика.

\section{Экономически зависимый самозанятый: уязвимость «переходного состояния» между предпринимателем и работником}

Один из основных отличительных признаков работника - это несамостоятельность его трудовой деятельности. Причем не только в смысле подконтрольности и управляемости со стороны работодателя, но и в организационной зависимости от последнего [20. Р. 490]. Тогда как предприниматель осуществляет деятельность на свой страх и риск и самостоятельно организует собственную деятельность. В реальной жизни не все так однозначно. Индивидуальный предприниматель или самозанятый (в узком понимании налогового законодательства РФ), выполняя работы или оказывая услуги по договору гражданско-правового характера, может по условиям договора выполнять работу из материалов и средствами заказчика, под контролем заказчика и, мало того, длительное время взаимодействовать с одним и те же заказчиком, получая от него преимущественную долю своих доходов.

Еще один из важных, квалифицирующих признаков самозанятого, чье положение максимально схоже со статусом работника, когда он становится «более сотрудником, нежели предпринимателем», - это неиспользование им труда других работников [21. Р. 36].

Осознавая всеобщность проблем определения статуса наемного работника с целью обеспечения реализации трудовых прав, Международная организация труда в 2006 г. утвердила Рекомендацию о трудовом правоотношении № 198, которая, кроме прочего, указывает критерии, позволяющие определить факт наличия трудового отношения тогда, «когда предпринимаются попытки (его) замаскировать» [22]. В пункте 13 Рекомендаций перечислены основные признаки трудового отношения, при наличии которых отношение должно признаваться трудовым в целях защиты работника независимо от того, на основании соглашения какого вида оно возникло. Для осуществления контроля за исполнением Рекомендации № 198 Международному бюро труда было поручено разработать Руководство по ее применению, что и было сделано в 2007 г. на основании материалов, подготовленных группой экспертов из разных стран [23]. В разделе 6 Рекомендаций отдельно приводятся примеры национальных практик, применяемых в различных правопорядках с целью дезавуировать недобросовестные попытки скрыть трудовые отношения, поскольку это лишает работников надлежащей защиты [21. С. 42].

С целью определения специфики правового положения экономически зависимого от заказчика самозанятого, признания за ним трудовых прав в зарубежных правопорядках принято применение таких терминов, как «лже самозанятый», «зависимый самозанятый», «экономически зависимый самозанятый» (Испания), «зависимый подрядчик» (Швеция), «зависимый предприниматель» и «зависимые самостоятельно занятые» (Великобритания), «автономный работник», «лицо, схожее с работником» (Австрия) и «лицо, похожее на сотрудника» (Германия) или «квази-работник» (Бельгия) и т.п. Но даже существующее правовое регулирование и устоявшаяся в законодательстве терминология могут подвергаться критике. Например, Миа Рённмар предлагает использовать категорию «квазисотрудник», хотя в шведским трудовом законодательстве существуют нормы, адресованные «зависимым подрядчикам» [24. Р. 163]. Такой расширительный подход можно расценить как реакцию на потребности расширить указанную категорию за счет лиц, занятых и франчайзингом [25. Р. 45; 26. Р. 70].

Сегодня многие ученые, изучающие проблемы самозанятости, отмечают увеличение числа зависимых самозанятых в «серой зоне», что означает высокий риск социального демпинга и трудового насилия [27].

Проблема определения статуса экономически зависимых самозанятых представляется неоднозначной и запутанной. Некоторые британские ученые давно указывают на неопределенность положения «зависимых самозанятых». Для достижения «равного обращения» ими предлагается приравнивать таких самозанятых в области заработной платы, рабочего времени и занятости к работникам при условии заключения договора об оказании личных услуг, от которых они получают бо́льшую часть 
своих доходов [21. Р. 37]. Несмотря на то что научное сообщество Великобритании обсуждает эти проблемы с конца XX в., только в 2018 г. лейбористская партия внесла в Британский парламент законопроект, который предлагает приравнять самозанятых к работникам в части прав на отпуск в связи с рождением ребенка [28].

Значительная же часть ученых рассматривают проблемы гибкости трудового права по отношению к экономически зависимым самозанятым в контексте их борьбы за получение коллективного представительства, реализацию права на свободу ассоциации в целях ведения коллективных переговоров, распространение на них коллективных договоров и соглашений, предоставление трудовых гарантий и получение прав в области социального страхования без какой бы то ни было дискриминации [21, 29].

Итак, можно говорить о необходимости отдельного правового регулирования «экономически зависимой работы» [29] и усиления защиты самозанятых. Конечно, в разных странах это регулирование осуществляется по-разному, значительно отличаются уровни социальной защиты указанных лиц, что можно объяснить и разницей в экономическом развитии, и особенностями, присущими национальным правовым системам.

\section{Специальное законодательство как способ предоставления социально-трудовых прав самозанятым}

Один из наиболее радикальных способов избежать жесткого разделения статуса работника и зависимого самозанятого и обеспечить законодательную защиту самозанятых - это принятие специального законодательства о самозанятых, которое распространяет на них целый ряд традиционных трудовых прав работников.

В 2007 г. в Испании был принят первый в ЕС законодательный акт, специально предназначенный для регулирования договорных условий труда самозанятых работников, предоставив им правовую защиту, очень похожую на защиту наемных работников [30].

Закон устанавливает отдельную категорию зависимых самозанятых работников [29. Р. 22-23], относя к ним тех, кто обычно и лично осуществляет экономическую или профессиональную деятельность, непосредственно и преимущественно для физического или юридического лица, называемого клиентом, от которого экономически зависит, получая от него, по крайней мере, $75 \%$ дохода.

Чтобы считаться зависимым самозанятым работником необходимо:

a) не иметь наемных работников и не заключать субподрядные контракты, т.е. не передавать исполнение части или всех обязательств третьим лицам;

б) не выполнять работу, идентичную услугам, оказываемым наемными работниками, нанятыми клиентом (иначе речь будет идти о ложно самозанятых, на которых этот закон не распространяется, но они признаются судом работниками); в) иметь собственную производственную инфраструктуру и материалы, необходимые для осуществления своей деятельности, независимо от инфраструктуры и материалов клиента, когда они имеют экономическое значение для указанной деятельности;

г) осуществлять свою деятельность с использованием собственных организационных и технических ресурсов;

д) получать согласованное с клиентом вознаграждение в зависимости от результата деятельности, осуществляемой на свой страх и риск.

При этом есть две серьезные практические проблемы. Во-первых, условие зависимости самозанятого работника должно быть прямо указано в договоре, а заказчик может этому препятствовать. Во-вторых, существует проблема доказывания существования этой экономической зависимости. Это чрезвычайно важный вопрос для компаний-клиентов, потому что, кроме случаев эксклюзивности, они должны верить на слово самозанятому.

Согласно испанскому закону все самозанятые имеют такие основные права, как равенство и защита от дискриминации, право на охрану здоровья, физическое и психологическое благополучие, свободу вероисповедания, эффективную правовую защиту, право на труд, свободный выбор карьеры, право хозяйственной инициативы и свободной конкуренции, право интеллектуальной собственности, касающиеся их собственной работы, договорное обеспечение, право на вознаграждение, совмещение профессиональной и личной жизни, профессиональную подготовку и переподготовку.

Кроме того, зависимые самозанятые имеют право:

- на заключение соглашения, представляющего профессиональный интерес (Acuerdos de Interes Profesional; далее - AIP);

- коллективную защиту и защиту в целом;

- участие во внесудебных системах для решения коллективных проблем в соответствии с договоренностями AIP;

- обязательное страхование на случай временной нетрудоспособности, которое ранее было только добровольным;

- досрочный выход на пенсию за услуги, предоставляемые в условиях, которые являются вредными или опасными;

- пособие по безработице;

- оплачиваемый отпуск продолжительностью 18 дней в году, если большая продолжительность не предусмотрена контрактом или соглашением;

- выходные и праздничные дни;

- ограничение сверхурочных работ, продолжительность которых должна быть установлена в договоре и не превышать $30 \%$ от согласованного обычного времени;

- коррекцию своего графика с учетом их профессиональной и личной жизни;

- расторжение договора по ограниченному числу оснований: по взаимному согласию сторон; в связи со смертью, уходом на пенсию или инвалидностью; отказом работника; серьезным неисполнением обяза- 
тельств клиентом; по уважительной причине или в случае необходимости; в связи с насилием по признаку пола;

- возмещение ущерба в случае признания увольнения осуществленным без уважительных причин;

- временное приостановление деятельности: при наличии обоюдного согласия; в связи с семейными обязанностями; серьезной угрозой для жизни или здоровья самозанятого работника; временной нетрудоспособностью; материнством или отцовством; насилием по признаку пола или форс-мажором;

- рассмотрение споров судом по социальным и трудовым вопросам;

- рассмотрение споров специализированными внесудебными органами по урегулированию конфликтов, в том числе обязательным арбитражем.

Таким образом, испанский закон о самозанятости представляет собой воплощенную концепцию «от трудового права к трудовым правам» [31. Р. 231], а именно формирует систему трудовых прав лиц, формально не являющихся субъектами трудового права. В развитие этого закона в Испании были приняты и другие нормативные правовые акты, посвященные регулированию труда самозанятых, например, королевский указ, в соответствии с которым разрабатываются Автономный статут труда, касающийся трудового договора с самозанятым работником и его регистрации, а также Государственный реестр профессиональных объединений самозанятых работников [32]. Мало того, в 2018 г. Правительство Испании разработало закон, призванный «покончить с “фальшивым предпринимательством”», который гласит, что работники, предлагающие свои услуги компании, приравниваются к ее персоналу» [33].

\section{Распространение отдельных норм трудового права на самозанятых как способ устранения недобросовестных практик на рынке труда}

В целом ряде стран в отдельных законах о труде содержатся нормы, распространяющие их действие (как правило, в определенной части) на самозанятых. Национальное законодательство в таких случаях устанавливает критерии, согласно которым самозанятый признается зависимым. Например, в Австрии к экономически зависимым самозанятым (лицам, схожим с работниками) относят лиц, которые выполняют работы (оказывают услуги) за счет другого лица, не заключая трудовой договор. При этом работа выполняется в пользу одного или очень ограниченного круга лиц, не используются собственные производственные ресурсы, вознаграждение является основным источников средств к существованию [23. Р. 43]. Такие лица не приравниваются к работникам полностью, к ним применяются только отдельные нормы трудового права, например, о трудовых судах, запрете дискриминации, заемном труде, охране труда и некоторые другие.

Германия разработала уникальные нормы, касающиеся самозанятых. В немецком законодательстве представлена категория «лица, похожие на сотрудников», которые имеют статус предпринимателей, вы- полняют работу лично для одного клиента либо зарабатывают не менее половины своего дохода только из одного источника. Такие предприниматели имеют доступ к некоторым институтам немецкого трудового права, они могут вступать в трудовые споры и заключать коллективные договоры, или вступать аналогично работникам в индивидуальные споры, которые рассматриваются в суде по трудовым спорам. Такие лица (подобные работникам) могут также признаваться субъектами системы социального обеспечения наравне с работниками. В то же время они пользуются некоторой автономией самозанятых, поскольку работодатели (заказчики) не могут диктовать им место и время выполнения работы. В отличие от испанского закона, в законодательстве Германии нет самостоятельного закона, но соответствующие положения содержатся в Законе о тарифном (коллективном) договоре [34], которые распространяются и на самозанятых. Кроме того, немецкое законодательство устанавливает меньший уровень экономической зависимости самозанятых по сравнению с испанским законодательством, требуя, чтобы более $50 \%$ дохода работника было получено от одного заказчика. Кроме того, немецкое законодательство содержит некоторые общие положения, которые применяются как к наемным работникам, так и к самозанятым. Например, предусмотрен 24-дневный оплачиваемый отпуск специально для зависимых самозанятых [35].

Схожие подходы к регулированию труда самозанятых прослеживаются и в некоторых других европейских правопорядках. В Италии самозанятые трудящиеся также могут пользоваться правом на ведение коллективных переговоров и могут быть представлены профсоюзными органами, призванными в основном защищать наемных работников.

В шведским трудовом законодательстве используется термин «зависимый подрядчик». Эта категория в шведское коллективное трудовое право была ведена еще в 1940-х г. и сохранилась в действующих сегодня законах, которые предоставляют зависимым подрядчикам те же права, что и работникам в части свободы ассоциации, коллективных договоров, прав на информацию, безопасности труда, социального страхования (в том числе от безработицы) и т.п. [24. Р. 163]. И хотя многие считают, что применение труда зависимых подрядчиков в Швеции перестало быть актуальным, другие предлагают расширить сферу действия коллективного трудового права на лиц, работающих в бизнесе франчайзинга [25. Р. 70].

В тех странах, где отсутствуют нормативное регулирование феномена самозанятости или нормы трудового права, описывающие признаки трудового отношения, позволяющие четко отграничивать друг от друга трудовые и гражданско-правовые отношения по выполнению физическими лицами работ или оказания услуг, вопросы гибкости трудоправового регулирования, тем не менее, могут стать предметом судебного разбирательства. Например, в Южно-Африканской Республике закон исключает независимого подрядчика из сферы действия трудового и социального законодательства, но судам, тем не менее, приходится рассматривать дела, связанные с разграничением ра- 
ботника и независимого подрядчика, используя подход «доминирующего впечатления». Причем без должного выяснения содержания фактически сложившихся отношений, что критикуется ученымиюристами [36]. В качестве положительного опыта в этой связи приводится практика США, где независимым подрядчиком признается тот, кто предоставляет услуги «широкой публике», имеет ряд клиентов, несет экономический риск потери работы. Подрядчики же, которые экономически зависят от лица, для которого они выполняют услуги в целом, должны рассматриваться как работники. Такие факторы, как низкая заработная плата, низкий уровень квалификации и наличие одного или нескольких работодателей, должны препятствовать признанию лица в качестве независимого подрядчика [37].

\section{Защита зависимых самозанятых коллективным договором: светлый идеал или коллизия с нормами антимонопольного законодательства?}

В разных странах, в том числе странах ЕC, правовое регулирование и степень защиты самозанятых находятся на совершенно разных уровнях.

В отсутствие специального законодательного регулирования труда зависимых самозанятых особо актуальным становится вопрос о распространении на них свободы ассоциации и коллективных переговоров. Конечно, распространение на зависимых самозанятых коллективных договоров и тарифных соглашений, действующих в конкретной организации, способно максимально уровнять их в правах с работниками, особенно касательно гарантий в сфере оплаты труда. Но здесь существуют объективные экономические, социальные и правовые препятствия. И сводятся они не только к пробелам правового регулирования и традиционной сферы применения трудового законодательства. Этот вопрос как раз может быть решен путем внесения соответствующих норм в действующее национальное законодательство, расширяющих сферу действия коллективного трудового права, как уже сделано в отдельных странах, упоминаемых выше.

Гораздо более сложной проблемой является реальная возможность и желание зависимых самозанятых присоединяться к профсоюзному движению, а у профсоюзов - защищать права тех, кто может умышленно с помощью приобретения статуса самозанятого уклоняться от страховых обязательств с целью получения преимуществ на рынке труда. Тем не менее нарастающие проблемы профсоюзов, связанные с прокаризацией рынка труда и уменьшением численности их членов, а значит, и снижающие авторитет, могут привести к смягчению позиции к самозанятым, как потенциальным участникам ассоциации. Если говорить об интересах самих зависимых самозанятых то следует присоединиться к мнению тех исследователей, которые выступают за расширение их прав при проведении коллективных переговоров [38]. Здесь следует отметить, что, например, в Нидерландах эта проблема решена полностью, поскольку зависимым самозанятым, как и работникам, предоставлено право на объединение в профсоюзы и право на коллективные переговоры [39. Р. 164].

Распространению в ЕС практики ведения коллективных переговоров самозанятыми, в том числе и в целях установления минимальной оплаты, во многом препятствует Европейское законодательство о конкуренции.

Важным с точки зрения европейской юриспруденции является недавно вынесенное судебное решение по делу Голландского профсоюза работников оркестpa «FNV Kunsten Informatie en Media» [40], где pacсмотрен вопрос о том, ограничиваются ли минимальные выплаты для самозанятых, установленные коллективным договором, положениями законодательства ЕС о конкуренции. Суд в итоге уклонился от оценки этого вопроса, сославшись на то, что «замещающие основных оркестрантов самозанятые» - это «ложные самозанятые», и поэтому они на деле являются сотрудниками. В указанном случае суд посчитал, что решающее значение имеет реалистичное определение того, является ли поставщик услуг подчиненным работодателя. А значит, самозанятые были признаны работниками, на которых распространяются гарантийные нормы по минимальной зарплате, установленные коллективным договором. При этом проблема коллизий норм конкурентного и коллективного трудового права осталась без судебной оценки.

В Европе коллективно-договорное установление минимальных выплат для самозанятых возникает в первую очередь (если вообще возникает) из национального трудового законодательства. В Нидерландах, как уже отмечалось выше, такую минимальную плату можно включить в коллективный договор. Там Закон о коллективном труде 1927 г. включает следующее положение: «...коллективный трудовой договор может также относиться к договорам на выполнение конкретной работы и договорам на оказание профессиональных услуг» [41]. Тем не менее некоторые положения законодательства ЕС, как представляется, создают проблемы для выплат самозанятым, устанавливаемых на национальном уровне, на основании или закона, или коллективных договоров.

ЕС объявляет вне закона соглашения между предприятиями, ограничивающие конкуренцию на рынке ЕС (ст. 101 ДФЕС [42]). Самозанятые лица, действующие как физические лица или наниматели очень небольшого штата, квалифицируются в качестве предприятий для целей законодательства о конкуренции, поскольку они предлагают услуги и товары на рынке. В этой связи следует упомянуть Решение Европейской Комиссии от 24 июня 2004 г. по поводу принятой Бельгийской ассоциацией архитекторов шкалы тарифов, согласно которому соглашение о минимальных тарифах архитекторов признано горизонтальным сговором лиц, представляющих интересы предприятий, а значит - односторонним решением, нарушающим законодательство о конкуренции [43].

При этом коллективные договоры могут быть исключены из запрета ст. 101(1) ДФЕС, если будут соблюдены определенные необходимые условия. Вопервых, соглашение должно быть результатом кол- 
лективных переговоров между организациями, представляющими работодателей и работников. Вовторых, коллективный договор должен непосредственно способствовать улучшению условий труда работников [44].

В США односторонние действия профсоюза в принципе освобождаются от антимонопольного законодательства, если профсоюз действует в собственных интересах и не объединяется с нетрудовыми группами. Основным прецедентом в этом вопросе является решение по делу Кэрролл [45]. Спор касался того, что американская Федерация музыкантов требовала от руководителей оркестров взимать со своих клиентов минимальные цены. Верховный Суд пришел к выводу, что руководители оркестра, работающие не по найму, действительно являлись «рабочей группой» и были вовлечены в «трудовой спор», поскольку существовала «конкуренция за работу или заработную плату или какая-либо другая экономическая взаимосвязь, затрагивающая законные интересы профсоюза, между членами профсоюза и независимыми подрядчики». Суд определил, что профсоюз может объединяться с независимыми подрядчиками, если «работа и функции, выполняемые независимыми подрядчиками, фактически или потенциально затрагивают время, заработную плату, гарантии занятости или условия труда членов профсоюза в одной и той же отрасли». Таким образом, с помощью прецедента решается вопрос о возможностях предоставления трудовых гарантий работников зависимых самозанятых лиц [44].

Антимонопольное законодательство США разрешает профсоюзам, включающим как наемных работников, так и самозанятых, в одностороннем порядке устанавливать взносы, обязательные для самозанятых членов профсоюза, когда эти сборы влияют на заработную плату работников. Однако антимонопольное законодательство США запрещает организациям, состоящим исключительно из самозанятых, вести коллективные переговоры с клиентами о минимальном размере их оплаты. Существует множество норм трудового законодательства США, которые мешают работникам и самозанятым объединяться для заключения сделок с клиентами самозанятых, даже если такие переговоры не нарушают антимонопольное законодательство США. Действительно, в соответствии со статьей 8(e) национального Закона «О трудовых отношениях» [46] даже профсоюзу, членами которого являются исключительно наемные работники, не разрешается заключать соглашение со своим работодателем, запрещающее последнему нанимать самозанятых лиц, которые не получают установленного минимального вознаграждения (29 U. S. с. $\S 158($ e)). Вместе с тем существуют отдельные исключения из раздела 8(е) для швейной и строительной отраслей, в которых независимые подрядчики, работающие не по найму, являются весьма распространенным явлением. В указанных секторах профсоюз работников может на законных основаниях вести переговоры со своим работодателем о размере вознаграждения независимых подрядчиков, нанятых работодателем.

\section{Заключение}

Можно с уверенностью сказать, что доля самозанятых в экономике в современных условиях, связанных с глобальными изменениями на рынке труда (прекаризация труда, автоматизация и роботизация производственных процессов, цифровизация экономики), будет продолжать расти. Этот рост влечет за собой целый ряд социально-экономических рисков, которые государство не может позволить себе игнорировать. Это прежде всего рост теневой экономики, сужение финансово-экономической основы традиционных фондов общественного потребления, в том числе и обязательного социального страхования, бюджетный кризис в части реализации социальных программ, снижение уровня социальной защиты трудящихся (в широком понимании этого слова), а значит, риск социально-политической нестабильности и угроза хрупкому социальному миру.

Все эти обстоятельства и объясняют то пристальное внимание, которое сегодня в мире уделяется вопросам гибкого трудового права и изучению возможностей предоставления мер социальной защиты экономически зависимых от заказчика самозанятых, включая меры, традиционно предоставляемые наемным работникам.

Как видим, способы реагирования на вызовы расширения сферы применения экономически зависимой самозанятости в разных странах разные - от полного игнорирования проблемы на уровне законодательства с возможностями судебного разрешения споров о признании отношений трудовыми (ЮАР) до издания специального закона о самозанятых с предоставлением экономически зависимым самозанятым трудовых прав и гарантий, сопоставимых с правами и гарантиями наемных работников (Испания). Между этими двумя, казалось бы, крайними способами, существует множество вариантов, например:

- включение в законы о труде норм, распространяющих действие отдельных правил для наемных работников на зависимых самозанятых (Германия, Швеция);

- установление возможностей участия самозанятых в коллективно-договорном регулировании (Нидерланды);

- формирование системы судебных прецедентов, позволяющих квалифицировать отношения как трудовые (США) с одновременным нормативным закреплением признаков трудового отношения (США);

- законодательный запрет на заключение гражданских договоров с целью регулирования трудовых отношений с возможностью восстановления нарушенного права в результате нарушения этого запрета в суде (Польша, Россия) и др.

Во всех случаях фактически расширяется действие трудового права, хотя и с помощью различных средств.

Обращает на себя внимание неоднозначный новый тренд развития российского законодательства о самозанятых, мало того что происходит их искусственное разделение на индивидуальных предпринимателей и всех остальных, кто оказывает услуги физическим 
лицам. Это, кстати, отчасти нивелирует и может сделать латентной проблему экономически зависимых самозанятых, поскольку и те и другие могут находиться в фактической зависимости от одного основного заказчика работ или услуг. В случае вывода самозанятых, оказывающих услуги физическим лицам, из сферы действия трудового законодательства (что предлагает сегодня Минтруд) через суд признать отношения трудовыми с помощью норм ст. 11 и 15 ТК РФ можно будет только тем лицам, которые заключили гражданско-правовой договор об оказании услуг с юридическим лицом или ИП в целях осуществления последним предпринимательской деятельности. Таким образом, уровень защиты остальных зависимых самозанятых упадет ниже минимального предела всяких международных стандартов.

Представляется, что сегодня основная проблема российского правотворчества в отношении регулирования деятельности самозанятых заключается в неверном определении приоритетов, главные из них вывод самозанятых из тени, борьба с теневой экономикой, перспектива расширения налоговой базы и повышение собираемости налогов. Однако все приведенные выше примеры международного подхода к проблемам самозанятых и экономически зависимых самозанятых, как и примеры зарубежного гибкого применения трудового права и частичного расширения сферы его действия, говорят о других приоритетах международной и зарубежной повестки. Только защищенные в правовом смысле самозанятые могут рассматриваться как стабильная часть рынка труда, а экономические результаты их деятельности - как часть ВВП страны и основа ее финансовой и бюджетной обеспеченности. Непродуманные решения в этой сфере способны еще в большей степени прокаризировать рынок труда и загнать «в тень» доходы наименее защищенных групп экономически активного населения, выводя его за пределы формальной занятости.

Обобщая зарубежный опыт, можно сделать вывод, что в России еще предстоит осмыслить и начать решать проблемы, связанные с искусственным выводом из сферы действия трудового права самозанятых, которые занимаются экономически зависимой от одного заказчика-работодателя деятельностью.

\section{ЛИТЕРАТУРА}

1. Федеральный закон от 30.11.2016 № 401-Ф3 «О внесении изменений в части первую и вторую Налогового кодекса Российской Федерации и отдельные законодательные акты Российской Федерации» // С3 РФ. 2016. № 49. Ст. 6844.

2. Федеральный закон от 26.07.2017 №199-Ф3 «О внесении изменений в статьи 2 и 23 части первой Гражданского кодекса Российской Федерации» // СЗ РФ. 2017. № 31 (ч. І). Ст. 4748.

3. Федеральный закон от 27.11.2018 № 422-Ф3 «О проведении эксперимента по установлению специального налогового режима «Налог на профессиональный доход» в городе федерального значения Москве, в Московской и Калужской областях, а также в Республике Татарстан (Татарстан)» // СЗ РФ. 2018. № 49 (ч. І). Ст. 7494.

4. Малис Н.И. Новые правила налогообложения микробизнеса должны способствовать росту налоговых поступлений // Налоги и финансы. 2017. № 4. С. 40-45.

5. Лысенко Е.Д. Актуальные проблемы правового регулирования самозанятости // Публично-правовые исследования (электронный журнал). 2017. № 2. С. 1-11.

6. Федеральная налоговая служба. Статистика по самозанятым гражданам. URL: https://www.nalog.ru/rn77/related_activities/statistics and analytics/selfemployed/ (дата обращения: 9.02.2019).

7. URL: http://tass.ru/ekonomika/5229974 (дата обращения: 9.02.2019).

8. Горелова И. «Всем выйти из сумрака»: какие изменения ждут самозанятых в 2019 году. URL: https://v1.ru/text/longread/business/ 65656161/ (дата обращения: 9.02.2019).

9. Роструд. Трудовые ресурсы. URL: http://www.gks.ru/wps/wcm/connect/rosstat_main/rosstat/ru/statistics/ wages/labour_force/\# (дата oбpaщения: 9.02.2019).

10. В ФНС уже признают эксперимент с самозанятыми успешным // Новые известия. 2019.15 января. URL: https://newizv.ru/news/economy/15-01-2019/v-fns-priznali-eksperiment-s-samozanyatymi-uspeshnym (дата обращения: 10.02.2019).

11. Попкова Ж.Г. Новая категория самозанятых лиц: проблемы правового статуса // Право и экономика. 2017 . № 2. С. 5-14.

12. Мишина И. Первые «ягодки»: Закон о самозанятых уже бьет по государству и работникам // Новые известия. 2019. 11 января. URL: https://newizv.ru/news/economy/11-01-2019/pervye-yagodki-zakon-o-samozanyatyh-udaril-po-gosudarstvu-i-rabotnikam дата обращения: 12.01.2019).

13. Проект Федерального закона «О внесении изменений в Трудовой кодекс Российской Федерации (в части совершенствования правового регулирования трудовых отношений отдельных категорий работников)». URL: http://www.consultant.ru/law/hotdocs/54427.html (дата обращения: 12.01.2019).

14. Решение Пролетарского районного суда г. Твери № 2-1325/2015 2-1325/2015 M-1081/2015 М-1081/2015 от 30 июня 2015 г. по делу № 2-1325/2015 по иску Щегловой A.Ю. к OAO «Московско-Тверская пригородная пассажирская компания». URL: https:/www.sudact.ru (дата обращения: 1.09.2018).

15. Постановление Пленума Верховного Суда РФ от 29.05.2018 № 15 «О применении судами законодательства, регулирующего труд работников, работающих у работодателей - физических лиц и у работодателей - субъектов малого предпринимательства, которые отнесены к микропредприятиям» // Бюллетень Верховного Суда РФ. 2018. № 7.

16. Постановление Восьмого арбитражного апелляционного суда от 7 июня 2018 г. по делу № A70-13715/2017. URL: https://www.sudact.ru/ (дата обращения: 10.02.2019).

17. Ustawa z dnia 26 czerwca 1974 r. Kodeks pracy (Dz.U. z 1974 r. nr 24, poz. 141). URL: http://prawo.sejm.gov.pl/ isap.nsf/DocDetails.xsp? id=WDU19740240141(дата обращения: 10.02.2019).

18. Rathod J.M., Skapski M. Reimagining the Law of Self-Employment: a Comparative Perspective // Hofstra Labor \& Employment Law Journal. 2013. Vol. 31, is. 1 .

19. Изменения в Трудовом кодексе Польши в 2018 году. URL: http://vsetutpl.com/ru/yzmenenyya-v-trudovom-kodekse-polshy-v-2018-godu (дата обращения: 10.02.2019).

20. Waas B. Heerma van Voss G. Restatement of Labour Law in Europe. Vol. I : The Concept of Employee Bloomsbury Publishing, 2017. 880 p.

21. Fudge J. Labour Protection for Self-Employed Workers // Just Labour. 2003. Vol. 3. P. 36-45.

22. Преамбула Рекомендации № 198 Международной организации труда «О трудовом правоотношении» (Принята в г. Женеве 15.06 .2006 на 95-й сессии Генеральной конференции МОТ) // СПС «КонсультантПлюс» (дата обращения: 14.02.2019). 
23. Regulating the Employment Relationship in Europe and Central Asia: a Guide to Recommendation No. 198 / International Labour Office, Governance and Tripartism Department. Geneva : ILO, 2014.

24. Rönnmar M. The Personal Scope of Labour Law and the Notion of Employee in Sweden // The 7th JILPT Comparative Labour Law Seminar. Tokyo, 9-10 March 2004. Tokyo, 2004. P. 159-165.

25. Bergqvist O., Lunning L. Toijer G Medbestämmandelagen: lagtext med kommentarer. Stockholm : Publica, 1997.595 p.

26. Engblom S. Self-Employment and the Personal Scope of Labour Law: Comparative Lessons from France, Italy, Sweden, the United Kingdom and the United States : EUI PhD theses. Florence, 2003. 314 p.

27. Coletto D., Pedersini R. Self-Employed Workers: Industrial Relations and Working Conditions (2009). URL: https://www.researchgate.net/ publication/268448326_Self-Employed_Workers_Industrial_Relations_and_Working_Conditions (дата обращения: 16.05.2018).

28. Hall J. This Law Could Give the Self-Employed the Same Rights as Employees // Simply Business. URL: https://www.simply business.co.uk/ knowledge/articles/2018/02/law-could-give-self-employed-workers-same-rights-as-employees/ (дата обращения: 06.05.2018).

29. Pedersini R., Coletto D. Self-Employed Workers: Industrial Relations and Working Conditions. Dublin : European Foundation for the Improvement of Living and Working Conditions, 2010. 66 p. URL: http://www.eurofound.europa.eu/docs/comparative/tn0801018s /tn0801018s.pdf (дата обращения: 11.02.2019)

30. Ley 20/2007, de 11 de julio, del Estatuto del trabajo autónomo. URL: http://noticias.juridicas .com/base_datos/Laboral/l20-2007.html (дата обращения: 09.02.2019).

31. Torres E.S. Self-Employed Worker: the Spanish Law on Dependent Self-Employed Workers: a New Evolution in Labor Law // 31 Comp. Lab. L. \& Pol'y J. 2010. № 31 .

32. Real Decreto 197/2009, de 23 de febrero, por el que se desarrolla el Estatuto del Trabajo Autónomo en materia de contrato del trabajador autónomo económicamente dependiente y su registro y se crea el Registro Estatal de asociaciones profesionales de trabajadores autónomos. URL: http://noticias.juridicas.com/base_datos/Laboral/rd 197-2009.html (дата обращения: 17.02.2019).

33. Власти Испании облегчат жизнь самозанятых граждан (30.10.2018). URL: http://noticia.ru/ allnews/ekonomika/vlasti-ispanii-oblegchatzhizn-samozanyatyh-grazhdan.htm (дата обращения: 16.02.2019).

34. Tarifvertragsgesetz 09.04.1949. Tarifvertragsgesetz in der Fassung der Bekanntmachung vom 25 August 1969 (BGBl. I S. 1323), das durch Artikel 5 des Gesetzes vom 11 August 2014 (BGBl. I S. 1348). URL: http://www.gesetze-im-internet.de/tvg/BJNR700550949.html (дата обpaщения: 13.02.2019).

35. Mindesturlaubsgesetz für Arbeitnehmer (Bundesurlaubsgesetz) 196308 Januar. URL: http://www.gesetze-im-internet.de/burlg/ (дата обращения: 13.02.2019).

36. Fourie E.S. Non-standard workers: the South African context, International law and regulation by the European Union // Potchefstroomse Elektroniese Regsblad - Potchefstroom Electronic Law Journal. 2008. Vol. 11, № 4. P. 110-152.

37. Benjamin P. An Accident of History: Who is (and Who Should be) an Employee Under South African Labour Law? // Industrial Law Journal (Juta). 2004. Vol. 25. P. 787-804.

38. Stone K.V.W. Legal Protections for Atypical Employees: Employment Law for Workers Without Workplaces and Employees Without Employers // Berkeley Journal of Employment and Labor Law. 2006. № 27 (2). P. 253-286.

39. Westerveld M. The 'New' Self-Employed: An Issue for Social Policy? // European Journal of Social Security. September 2012. № 14 (3). P. 156-173.

40. Judgment of the Court (First Chamber), 4 December 2014. FNV Kunsten Informatie en Media V Staat der Nederlanden. URL: https://curia.europa.eu/jcms/jcms/P_106320/fr/?rec=RG\&jur=C\&anchor=201412C0354 \#201412 C0354 (дата обращения: 13.02.2019).

41. Artikel 1 (2) Wet van 24 december 1927, houdende nadere regeling van de Collectieve Arbeidsovereenkomst. URL: https://www.businesslegal consultancy.com/nl/wet-van-24-december-1927-houdende-nadere-regeling-van-de-collectieve-arbeidsovereenkomst/ (дата обращения: 14.02.2019).

42. Договор о функционировании Европейского Союза (англ. Treaty on the Functioning of the European Union, TFEU). URL: http://eulaw.ru/treaties/tfeu (дата обращения: 14.02.2019).

43. Commission of the European Communities. Commission Decision of 24 June 2004 relating to a proceeding under Article 81 of the EC Treaty. URL: http://ec.europa.eu/competition/antitrust/cases/dec_docs/38549/38549_72_1.pdf (дата обращения: 13.02.2019).

44. Grosheide E., Barenberg M. Minimum Fees for the Self-Employed: a European Response to the «Uber-Ized» Economy? // Colum. J. Eur. L. 2016. № 22. P. 193.

45. Fed'n of Musicians v. Carroll, 391 U.S. 99, 104 (1968). URL: https://supreme.justia.com/cases/federal/us/391/99/

46. Титул 29, глава 7, подглава II, Свод законов США. URL: https://www.nlrb.gov/ sites/default/files/attachments/basic-page/node-4094/the-nlratext-of-the-act-rus.pdf (дата обращения: 17.02.2019).

Статья представлена научной редакцией «Право» 4 марта 2019 г.

The Economically Dependent Self-Employed: Differences in National Approaches to the Determination of Their Legal Status Vestnik Tomskogo gosudarstvennogo universiteta - Tomsk State University Journal, 2019, 446, 212-222.

DOI: $10.17223 / 15617793 / 446 / 28$

Larisa V. Zaitseva, University of Tyumen (Tyumen, Russian Federation). E-mail: l.v.zajceva@utmn.ru

Keywords: field of labor law in terms of individuals; self-employed; collective agreement; minimum wage.

The aim of this research is to identify the most effective mechanisms for countering the practice of "unfair competition" in the labor market with the participation of the self-employed. To achieve the aim, the features of the legal status of the economically dependent self-employed in various modern legal orders are examined. In this research, the author analyzed the regulatory legal acts and court practice of the Russian Federation, Austria, Belgium, Germany, Italy, Spain, the Netherlands, Norway, Poland, the USA, Sweden, the Republic of South Africa on the regulation of dependent self-employed activities, recognition of civil law labor relations, widespread use of collective contractual regulation and its interaction with competition law. The documents of the International Labor Organization and the European Union, as well as publications of Russian and foreign researchers on the subject of the article were studied. The main methodological approaches in the study were comparative studies, the method of expert assessments, analysis and synthesis, formal legal and functional methods. The author found out that the modern labor market is characterized by an increase in the number of self-employed persons and a decrease in the number of employees. It can therefore be concluded that these processes narrow the scope of labor law, worsen the working conditions and the level of social protection for both self-employed people and employees. Since this problem is acquiring a global character, the article summarizes different national approaches to the regulation of the labor of the self-employed, to the determination of their legal status and the possibility of a flexible application of labor law norms to them. The phenomenon of self-employment for modern Russia was actualized. The article demonstrates a traditional labor law method for solving the problems of concealing an employment relationship for an employer to obtain illegal prefer- 
ences. Different national practices existing in the Russian Federation and in other countries were compared. The author identified signs of economically dependent self-employed persons in different legal orders that separate them from other self-employed and employees. The problems arising from the provision of collective bargaining rights to the self-employed from the standpoint of antitrust legislation were studied. As a result, the general problems and priorities of legal policy in this area have been identified, and the ways in which the national labor market is protected from "social dumping" existing in different countries have been generalized by bringing the status of economically dependent self-employed persons close to that of employees. The conclusion is made about the imperfection of the priorities of the legal policy of the Russian Federation in the field of the regulation of the self-employed. The policy aims at using monetary methods to withdrawing the self-employed "out of the shadow" to the detriment of social protection with the risk of the deterioration of working and employment conditions.

\section{REFERENCES}

1. Russian Federation. (2016) Federal’nyy zakon ot 30.11.2016 № 401-FZ “O vnesenii izmeneniy v chasti pervuyu i vtoruyu Nalogovogo kodeksa Rossiyskoy Federatsii i otdel'nye zakonodatel'nye akty Rossiyskoy Federatsii” [Federal Law No. 401-FZ of 30 November 2016 “On Amendments to Parts One and Two of the Tax Code of the Russian Federation and Certain Legislative Acts of the Russian Federation”]. SZ RF. 49. Art. 6844.

2. Russian Federation. (2017) Federal’nyy zakon ot 26.07.2017 №199-FZ “O vnesenii izmeneniy v stat’i 2 i 23 chasti pervoy Grazhdanskogo kodeksa Rossiyskoy Federatsii” [Federal Law No. 199-FZ of 26 July 2017 “On Amending Articles 2 and 23 of Part One of the Civil Code of the Russian Federation"]. SZ RF. 31 (I). Art. 4748.

3. Russian Federation. (2018) Federal’nyy zakon ot 27.11.2018 № 422-FZ “O provedenii eksperimenta po ustanovleniyu spetsial’nogo nalogovogo rezhima "Nalog na professional’nyy dokhod” v gorode federal’nogo znacheniya Moskve, v Moskovskoy i Kaluzhskoy oblastyakh, a takzhe v Respublike Tatarstan (Tatarstan)" [Federal law No. 422-FZ of 27 November 2018 "On the experiment to establish a special tax regime "Profit Tax" in the city of federal significance Moscow, in Moscow and Kaluga Oblast, as well as in the Republic of Tatarstan (Tatarstan)”]. SZ RF. 49 (I). Art. 7494.

4. Malis, N.I. (2017) New rules of taxation of microbusiness should provide increasing of tax receipts. Nalogi i finansy. 4. pp. 40-45. (In Russian).

5. Lysenko, E.D. (2017) Aktual'nye problemy pravovogo regulirovaniya samozanyatosti [Topical issues of legal regulation of self-employment]. Publichno-pravovye issledovaniya. 2. pp. 1-11.

6. Federal Tax Service of Russia. (2019) Statistika po samozanyatym grazhdanam [Statistics on self-employed citizens]. [Online] Available from: https://www.nalog.ru/rn77/related_activities/statis-tics_and_analytics/selfemployed/. (Accessed: 9.02.2019).

7. TASS. (2018) The State Duma passed in the first reading a bill on the accounting of self-employed citizens in tax authorities. [Online] Available from: http://tass.ru/ekonomika/5229974. (Accessed: 9.02.2019). (In Russian).

8. Gorelova, I. (2018) "Vsem vyyti iz sumraka": kakie izmeneniya zhdut samozanyatykh v 2019 godu ["Out of the gloom, everyone”: what changes await the self-employed in 2019]. [Online] Available from: https://v1.ru/text/longread/business/65656161/. (Accessed: 9.02.2019).

9. Gks.ru. (2018) Rostrud. Trudovye resursy [Rostrud. Labor resources]. [Online] Available from: http://www.gks.ru/wps/wcm/connect/rosstat_ main/rosstat/ru/statistics/wages/labour_force/\#. (Accessed: 9.02.2019).

10. Novye izvestiya. (2019) V FNS uzhe priznayut eksperiment s samozanyatymi uspeshnym [The Federal Tax Service has already recognized the experiment with the self-employed as successful]. 15 January. [Online] Available from: https:/newizv.ru/news/economy/15-01-2019/v-fnspriznali-eksperiment-s-samozanyatymi-uspeshnym. (Accessed: 10.02.2019).

11. Popkova, Zh.G. (2017) A new category of self-employed persons: issues of the legal status. Pravo i ekonomika. 2. pp. 5-14. (In Russian).

12. Mishina, I. (2019) Pervye "yagodki": Zakon o samozanyatykh uzhe b'et po gosudarstvu i rabotnikam [The first "berries": the law on the selfemployed already hits the state and workers]. Novye izvestiya. 11 January. [Online] Available from: https://newizv.ru/news/economy/11-012019/pervye-yagodki-zakon-o-samozanyatyh-udaril-po-gosudarstvu-i-rabotnikam. (Accessed: 12.01.2019).

13. Consultant.ru. (2018) Proekt Federal'nogo zakona "O vnesenii izmeneniy v Trudovoy kodeks Rossiyskoy Federatsii (v chasti sovershenstvovaniya pravovogo regulirovaniya trudovykh otnosheniy otdel'nykh kategoriy rabotnikov)" [The draft Federal Law "On Amendments to the Labor Code of the Russian Federation (in terms of improving the legal regulation of labor relations of certain categories of workers)”.]. [Online] Available from: http://www.consultant.ru/law/hotdocs/54427.html. (Accessed: 12.01.2019).

14. Sudact.ru. (2015) Decision of the Proletarsky District Court of Tver No. 2-1325/2015 2-1325/2015 M-1081/2015 M-1081/2015 of June 30, 2015, in case No. 2-1325/2015 in a lawsuit by A.Yu. Scheglova to OJSC Moscow-Tver Suburban Passenger Company. [Online] Available from: https://www.sudact.ru. (Accessed: 1.09.2018).

15. Supreme Court of the Russian Federation. (2018) Postanovlenie Plenuma Verkhovnogo Suda RF ot 29.05 .2018 № 15 “O primenenii sudami zakonodatel'stva, reguliruyushchego trud rabotnikov, rabotayushchikh u rabotodateley - fizicheskikh lits i u rabotodateley - sub”ektov malogo predprinimatel'stva, kotorye otneseny k mikropredpriyatiyam” [Resolution of the Plenum of the Supreme Court of the Russian Federation No. 15 of 29 May 2018 "On the application by the courts of laws regulating the labor of workers working with individual employers and with small business employers that are classified as microenterprises”]. Byulleten' Verkhovnogo Suda RF. 7.

16. Sudact.ru. (2018) Decision of the Eighth Arbitration Court of Appeal of June 7, 2018, in case No. A70-13715/2017. [Online] Available from: https://www.sudact.ru/. (Accessed: 10.02.2019). (In Russian).

17. ISAP. (1974) Ustawa z dnia 26 czerwca 1974 r. Kodeks pracy (Dz.U. z 1974 r. nr 24, poz. 141). [Online] Available from: http://prawo.sejm.gov.pl/isap.nsf/DocDetails.xsp?id=WDU19740240141. (Accessed: 10.02.2019).

18. Rathod, J.M. \& Skapski, M. (2013) Reimagining the Law of Self-Employment: a Comparative Perspective. Hofstra Labor \& Employment Law Journal. 31 (1).

19. Vsetut.pl. (2018) Izmeneniya v Trudovom kodekse Pol'shi v 2018 godu [Changes to the Polish Labor Code in 2018]. [Online] Available from: http://vsetutpl.com/ru/yzmenenyya-v-trudovom-kodekse-polshy-v-2018-godu. (Accessed: 10.02.2019).

20. Waas, B. \& Heerma van Voss, G. (eds) (2017) Restatement of Labour Law in Europe. Vol. I: The Concept of Employee. Bloomsbury Publishing.

21. Fudge, J. (2003) Labour Protection for Self-Employed Workers. Just Labour. 3. pp. 36-45.

22. Konsul'tantPlyus. (2006) Preamble to Recommendation No. 198 of the International Labor Organization “On the Labor Relations” (Adopted in Geneva on 15 June 2006 at the 95th session of the ILO General Conference). Moscow: Konsul'tantPlyus. (In Russian).

23. International Labour Office, Governance and Tripartism Department. (2014) Regulating the Employment Relationship in Europe and Central Asia: a Guide to Recommendation No. 198. Geneva: ILO.

24. Rönnmar, M. (2004) The Personal Scope of Labour Law and the Notion of Employee in Sweden. The 7th JILPT Comparative Labour Law Seminar. Tokyo. 9-10 March 2004. Tokyo. pp. 159-165.

25. Bergqvist, O. \& Lunning L. (1997) Toijer G Medbestämmandelagen: lagtext med kommentarer. Stockholm: Publica.

26. Engblom, S. (2003) Self-Employment and the Personal Scope of Labour Law: Comparative Lessons from France, Italy, Sweden, the United Kingdom and the United States: EUI PhD theses. Florence.

27. Coletto, F. \& Pedersini, R. (2009) Self-Employed Workers: Industrial Relations and Working Conditions. [Online] Available from: https://www.researchgate.net/publication/268448326_Self-Employed_Workers_Industrial_Relations_and_Working_Conditions. (Accessed: 16.05.2018). 
28. Hall, J. (2018) This Law Could Give the Self-Employed the Same Rights as Employees. [Online] Available from: https://www.simplybusiness.co.uk/knowledge/articles/2018/02/law-could-give-self-employed-workers-same-rights-as-employees/. (Accessed: 06.05.2018).

29. Pedersini, R. \& Coletto, D. (2010) Self-Employed Workers: Industrial Relations and Working Conditions. Dublin: European Foundation for the Improvement of Living [Online] Conditions. Available http://www.eurofound.europa.eu/docs/comparative/tn0801018s/tn0801018s.pdf. (Accessed: 11.02.2019).

30. Noticias Juridicas. (2007) Ley 20/2007, de 11 de julio, del Estatuto del trabajo autónomo. [Online] Available from: http://noticias.juridicas.com/base_datos/Laboral/l20-2007.html. (Accessed: 09.02.2019).

31. Torres, E.S. (2010) Self-Employed Worker: the Spanish Law on Dependent Self-Employed Workers: a New Evolution in Labor Law. CLLPJ. 31.

32. Noticias Juridicas. (2009) Real Decreto 197/2009, de 23 de febrero, por el que se desarrolla el Estatuto del Trabajo Autónomo en materia de contrato del trabajador autónomo económicamente dependiente y su registro y se crea el Registro Estatal de asociaciones profesionales de trabajadores autónomos. [Online] Available from: http://noticias.juridicas.com/base_datos/Laboral/rd 197-2009.html. (Accessed: 17.02.2019).

33. Noticia.ru. (2018) Vlasti Ispanii oblegchat zhizn' samozanyatykh grazhdan [The Spanish authorities will facilitate the life of self-employed citizens]. 30 October. [Online] Available from: http://noticia.ru/allnews/ekonomika/vlasti-ispanii-oblegchat-zhizn-samozanyatyh-grazhdan.htm. (Accessed: 16.02.2019).

34. Ein Service des Bundesministeriums der Justiz und für Verbraucherschutz sowie des Bundesamts für Justiz. (1949) Tarifvertragsgesetz 09.04.1949. Tarifvertragsgesetz in der Fassung der Bekanntmachung vom 25 August 1969 (BGBl. I pp. 1323), das durch Artikel 5 des Gesetzes vom 11 August 2014 (BGBl. I pp. 1348). [Online] Available from: http://www.gesetze-im-internet.de/tvg/BJNR700550949.html. (Accessed: 13.02.2019).

35. Ein Service des Bundesministeriums der Justiz und für Verbraucherschutz sowie des Bundesamts für Justiz. (1963) Mindesturlaubsgesetz für Arbeitnehmer (Bundesurlaubsgesetz) 196308 Januar. [Online] Available from: http://www.gesetze-im-internet.de/burlg/. (Accessed: 13.02.2019).

36. Fourie, E.S. (2008) Non-standard workers: the South African context, International law and regulation by the European Union. Potchefstroomse Elektroniese Regsblad - Potchefstroom Electronic Law Journal. 11 (4). pp. 110-152.

37. Benjamin, P. (2004) An Accident of History: Who is (and Who Should be) an Employee Under South African Labour Law? Industrial Law Journal. 25. pp. 787-804.

38. Stone, K.V.W. (2006) Legal Protections for Atypical Employees: Employment Law for Workers Without Workplaces and Employees Without Employers. Berkeley Journal of Employment and Labor Law. 27 (2). pp. 253-286.

39. Westerveld, M. (2012) The 'New’ Self-Employed: An Issue for Social Policy? European Journal of Social Security. September. 14(3). pp. 156173.

40. EU Court of Justice. (2014) Judgment of the Court (First Chamber), 4 December 2014. FNV Kunsten Informatie en Media $v$ Staat der Nederlanden. [Online] Available from: https://curia.europa.eu/jcms/jcms/P_106320/fr/?rec=RG\&jur=C\&anchor=201412C0354\#201412 C0354. (Accessed: 13.02.2019).

41. Business Legal Consultancy. (1927) Artikel 1 (2) Wet van 24 december 1927, houdende nadere regeling van de Collectieve Arbeidsovereenkomst. [Online] Available from: https://www.businesslegalconsultancy.com/nl/wet-van-24-december-1927-houdende-nadere-regeling-van-decollectieve-arbeidsovereenkomst/. (Accessed: 14.02.2019).

42. EU Law. (n.d.) Treaty on the Functioning of the European Union. [Online] Available from: http://eulaw.ru/treaties/tfeu. (Accessed: 14.02.2019). (In Russian).

43. Commission of the European Communities. (2004) Commission Decision of 24 June 2004 relating to a proceeding under Article 81 of the EC Treaty. [Online] Available from: http://ec.europa.eu/competition/antitrust/cases/dec_docs/38549/38549_72_1.pdf. (Accessed: 13.02.2019).

44. Grosheide, E. \& Barenberg, M. (2016) Minimum Fees for the Self-Employed: a European Response to the "Uber-Ized” Economy? Colum. J. Eur. L. 22.

45. Justia. (1968) Fed'n of Musicians v. Carroll, $391 \quad$ U.S. 99 , $104 \quad$ (1968). [Online] Available from: https://supreme.justia.com/cases/federal/us/391/99/.

46. Nlrb.gov. (n.d.) Code of Laws of the United States of America. Title 29. Chapter 7. Subchapter II. [Online] Available from: https://www.nlrb.gov/sites/default/files/attachments/basic-page/node-4094/the-nlra-text-of-the-act-rus.pdf. (Accessed: 17.02.2019). (In Russian).

Received: 04 March 2019 